\title{
Graph algorithms for machine learning: a case-control study based on prostate cancer populations and high throughput transcriptomic data
}

Gary L Rogers ${ }^{1 *}$, Pablo Moscato², Michael A Langston ${ }^{1}$

From UT-ORNL-KBRIN Bioinformatics Summit 2010

Cadiz, KY, USA. 19-21 March 2010

\section{Background}

The continuing proliferation of high-throughput biological data promises to revolutionize personalized medicine. Confirming the presence or absence of disease is an important goal. In this study, we seek to identify genes, gene products and biological pathways that are crucial to human health, with prostate cancer chosen as the target disease.

\section{Materials and methods}

Using case-control transcriptomic data, we devise a graph theoretical toolkit for this task. It employs both innovative algorithms and novel two-way correlations to pinpoint putative biomarkers that classify unknown samples as cancerous or normal.

\section{Results and conclusion}

Observed accuracy on real data suggests that we are able to achieve sensitivity of $92 \%$ and specificity of $91 \%$.

\section{Author details}

${ }^{1}$ Department of Electrical Engineering and Computer Science, University of Tennessee, Knoxville, TN 37996, USA. ${ }^{2}$ Department of Electrical Engineering and Computer Science, University of Newcastle, NSW, Australia.

Published: 23 July 2010

doi:10.1186/1471-2105-11-S4-P21

Cite this article as: Rogers et al:: Graph algorithms for machine learning: a case-control study based on prostate cancer populations and high throughput transcriptomic data. BMC Bioinformatics 2010 11(Suppl 4):P21.

\footnotetext{
* Correspondence: grogers@eecs.utk.edu

${ }^{1}$ Department of Electrical Engineering and Computer Science, University of Tennessee, Knoxville, TN 37996, USA
}

Submit your next manuscript to BioMed Central and take full advantage of:

- Convenient online submission

- Thorough peer review

- No space constraints or color figure charges

- Immediate publication on acceptance

- Inclusion in PubMed, CAS, Scopus and Google Scholar

- Research which is freely available for redistribution

Submit your manuscript at www.biomedcentral.com/submit
C BioMed Central 